\title{
Recenzja książki Maria, „Mutter der Einheit” (,Mater unitatis"), red. M. Hauke, Regensburg 2020, ss. 392
}

Deutsche Arbeitsgemeinschaft für Mariologie, w krajach języka niemieckiego odpowiednik Polskiego Towarzystwa Mariologicznego, zorganizowała w 2018 roku w Würzburgu konferencję naukową na temat: Maryja, Matki jedności. Konferencja znalazła żywy oddźwięk w mediach. Konferencyjne materiały, wygłoszone referaty, opublikowano wiosną 2020 roku w pracy zbiorowej pod takim samym tytułem jako 28. tom znanej i cenionej serii mariologicznej: Mariologische Studien. Manfred Hauke, redaktor publikacji, we wstępie do niej zwraca uwagę na to, że w XX wieku zaczęto coraz częściej nadawać Maryi tytuł: Mater unitatis (ss. 7-8). Wynika to z przekonania, że dzięki Jej przykładowi oraz macierzyńskiemu pośrednictwu jest Ona niezbędną ,,pomocą” w dziele chrześcijańskiej jedności.

Publikacja składa się z osiemnastu artykułów. Otwiera ją referat, który kończył konferencję w Würzburgu. Manfred Hauke panoramicznie przedstawia duchowe macierzyństwo Maryi wodniesieniu do Jej zatroskania o jedność (ss. 17-35). Wychodzi od trynitarnej jedności Boga w połączeniu z prawdą, dobrem i pięknem, które są podstawą każdej jedności, by w tym kontekście ukazać więź Maryi z tajemnicą Jezusa Chrystusa i Kościoła (Córa Syjonu, Nowa Ewa, Niewiasta Przymierza), a następnie Jej związek z Ojcem i Duchem Świętym w dziele budowania jedności. W końcowej części refleksji koncentruje się na nauczaniu Pawła VI i Jana Pawła II, którzy przyczynili się do recepcji tytułu „Matka jedności” w oficjalnej nauce Kościele. 
Po artykule wprowadzającym pojawiają się dwa artykuły biblijne. Regina Willi wypowiada się na temat Maryi jako Matki jedności w perspektywie Ewangelii Janowej (ss. 36-68), najpierw, by wykazać, że motyw jedności jest nośny w tej Ewangelii (Syn Boży przyszedł na świat, by zgromadzić w jedno rozproszone dzieci Boże), przeprowadza wnikliwe analizy egzegetyczne. W dalszej części refleksji przechodzi do omówienia roli, jaką wyznaczył Maryi Jezus Chrystus z wysokości krzyża: „Oto Syn Twój!”. W Janie, umiłowanym uczniu Jezusa, Kościół dostrzega osobowy symbol wszystkich wierzących. Maryja ma niezbędny udział w gromadzeniu ich w jedno. Jej rola jest wstawiennicza. Tak jak w Kanie Galilejskiej wskazała Synowi na potrzeby weselników, tak teraz wyprasza, abyśmy stali się otwarci na wyzwalające słowa i wydarzenia Jezusa Chrystusa.

Julian Backes zajmuje się z kolei teologicznym obrazem Maryi jako Matki jedności w pismach Łukaszowych (ss. 69-87). Podejmuje problem recepcji przez ewangelistę starotestamentalnego symbolu "Córa Syjonu”, który wskazywał najpierw na lud Boży, a on odniósł go do Maryi. Dlatego w słowach powitania anielskiego (przy zwiastowaniu) nawiązał do proroka Sofoniasza 3,14: „raduj się”, „łaski pełna”, aby wskazać, że jest Ona reprezentantką ludu Bożego i jego macierzyńskim znakiem jedności. Potwierdzają to kolejne perykopy ewangeliczne z Jej udziałem. W modlitewnym oczekiwaniu na zesłanie Ducha Świętego też okazała się łączniczką. W sumie jednak argumentacja J. Backesa jest dość zawiła - bardziej egzegetyczna niż teologiczna.

Tytuł „Matka jedności” pojawia się po raz pierwszy w kazaniu świętego Augustyna, stąd też Ursula Bleyenberg stara się odnaleźć jego teologiczne znaczenie (ss. 88-99). Zauważa, że Augustyn odnosi ten tytuł zarówno do Maryi, jak i do Kościoła. Kościół jest matką, która troszczy się o jedność swoich dzieci. Jednocześnie jednak dostrzega on, że jego osobowy prawzór znajduje się w Maryi. Tak jak jest Ona cielesną Matką i Dziewicą, tak Kościół jest w sensie duchowym matką wierzących. Maryja zrodziła Jezusa Chrystusa, Głowę Kościoła, a Kościół - za wzorem Maryi i z Jej matczyną pomocą - rodzi swoich członków. W ten sposób Maryja odgrywa doniosłą rolę w jednoczeniu ludzi z Jezusem Chrystusem.

W artykule Antona Ziegenausa, zatytułowanym Maryja w nestorianizmie, dochodzi do głosu Matka Boża jako obrończyni jedności w Jezusie Chrystusie (ss. 100-106). Autor w encyklopedyczny i przejrzysty sposób wykazuje, w jakim sensie efeski tytuł Theotokos broni jedności dwóch natur (boskiej i ludzkiej) w Osobie odwiecznego Syna Bożego, a z drugiej strony przedstawia, na czym polegały błędne założenia teologiczne nestorianizmu.

W następnym artykule Johannes Stöhr zwraca uwagę na neo-nestorianizm w eklezjologii (ss. 107-136), przesadnie oddzielający w Kościele to, co Boskie, od tego, co ludzkie, treść Objawienia Bożego od ludzkiego jego przekazu. Pro- 
wadzi to często do wniosku: Chrystus tak - Kościół nie, duch tak - instytucja nie. Wtedy podkreśla się autonomię tego, co ludzkie bądź zastępuje teologię antropologią. Boże Objawienie nie jest już locutio Dei, lecz pogłębieniem samorozumienia siebie. Maryja przywraca właściwą orientację w życiu wiary i rozumieniu Kościoła. Wskazuje na Jezusa Chrystusa (Hodegetria), prawdziwego Boga oraz prawdziwego człowieka, a jednocześnie dowodzi, że nie można, jak czyni to współczesny neo-nestorianizm w eklezjologii, ekstremalnie domagać się uwzględniania aktualnych sytuacji, które sprawiają, że słowa nie wyrażają w pełni zawartego w nich ewangelicznego przesłania.

Interesujący artykuł przedkłada Imre von Gaál. Przedstawia w nim znaczenie Maryi dla jedności chrześcijan w rozumieniu świętego Johna Henry’ego Newmana (ss. 137-156). Koncentruje się na jego 15. kazaniu uniwersyteckim i piśmie skierowanym do wcześniejszego towarzysza na drodze anglikańskiej - Edwarda Pusey'a. Wynika z nich, że święty widział w Maryi gwarantkę jedności. Bazując na przemyśleniach ojców Kościoła, doszedł do wniosku, że skoro Maryja, Nowa Ewa, jest Matką Bożą, to Jezus Chrystus jest dosłownie Immanuelem - Bogiem-z-nami. Fiat Maryi objęło całą ludzkość. Ona także, dzięki swej wierze, stała się pierwszą uczennicą Jezusa Chrystusa. W rezultacie jedynie „poprzez” Jezusa Chrystusa i „z” Maryją jest możliwe rozumienie Kościoła jako sakramentu zbawienia.

Ze strony nauczania papieskiego - jak twierdzi Rudolf Kirchgrabner - istotne są refleksje Leona XIII, który w wielu encyklikach na temat różańca postrzegał Maryję jako fautrix unitatis: krzewicielkę jedności, zwłaszcza na płaszczyźnie ekumenicznej (ss. 157-165). Akcentował Jej pośrednictwo i głęboką wiarę, bez której niemożliwe byłoby wcielenie Syna Bożego.

W przedłożeniu Stefana Toblera dochodzi do głosu Maryja w mistycznym doświadczeniu Chiary Lubich (ss. 166-189), założycielki ruchu Focolari. Od 1947 roku występuje regularnie w jej pismach tytuł: „Matka jedności”. Maryja jest postrzegana przez nią w ścisłym odniesieniu do Trójcy Świętej, Eucharystii i słowa Bożego. Jednocześnie występują u niej przedziwne sformułowania, takie jak na przykład nazywanie Maryi „,czwartą w Trójcy Świętej” (s. 178) bądź zrównywanie Jej macierzyństwa z uniwersalnym ojcostwem Boga. Szkoda, że autor nie podjął próby głębszego wyjaśnienia ich w duchu doświadczenia Ch. Lubich.

Burzliwe dyskusje wokół tytułu „Matka jedności” towarzyszyły obradom II Soboru Watykańskiego. Opisuje je Achim Dittrich (ss. 181-195), który opublikował monumentalne dzieło na temat historii i sensu tytułu: „Matka Kościoła”. Okazuje się, że fronty „za” i „przeciw” były porównywalne. Zwłaszcza niemieccy uczestnicy soboru - teolodzy i biskupi - sprzeciwiali się zamieszczeniu tytułu „Matka jedności” w dokumentach soborowych. Uważali, że jest on zbyt nowy, a ponadto może prowokować braci ewangelików, którzy mają pod adresem katolickiej mariologii liczne zastrzeżenia. Mimo iż nie znalazł się on 
w tekście soborowym, to jednak jego teologiczna treść została zasygnalizowana w numerze 69. konstytucji Lumen gentium. Dzięki Pawłowi VI, a potem Janowi Pawłowi II dokonała się jego recepcja po soborze.

Godne uwagi są stanowiska ewangelickich teologów, którzy wypowiadają się krytycznie o tym tytule i zarazem przedkładają własne refleksje na temat udziału Maryi w dziele jedności. Postawę Karla Bartha omawia wnikliwie chorwacki karmelita Ivan Podgorelec (ss. 198-215). Zauważa, że choć Barth podkreślał znaczenie fiat Maryi przy zwiastowaniu (dyspozycja), to jednak nie przyjmował Jej współdziałania w dziele odkupienia, ponieważ jest ono wyłącznie Boże. Nigdy ani nigdzie nie wypowiedział się explicite na temat udziału Maryi w promowaniu jedności chrześcijan. Krótko przed śmiercią wyraził jednak sugestię, że należy w protestantyzmie przemyśleć na nowo rolę i miejsce Maryi w historii zbawienia (s. 215).

$\mathrm{Ku}$ mariologii katolickiej oscylują na przykład refleksje Hansa Asmussena, luterańskiego teologa. Michael Stickelbroeck poświęca im kolejny artykuł (ss. 216-226). Okazuje się, że H. Asmussen wychodzi od podkreślenia wagi tytułu „Matka Boża”, który przyjmują także Kościoły poreformacyjne. Maryja stoi po stronie ludzi i dała ludzką naturę Jezusowi Chrystusowi. Nie można więc w Niej wszystkiego przypisywać łasce Bożej, ale można przyjąć Jej współpracę w oparciu o zasadę partycypacji. To prawda, że Jezus Chrystus jest jedynym Pośrednikiem między Bogiem i ludźmi, ale na bazie kapłaństwa istnieje możliwość zbawczej współpracy „w Chrystusie”, lecz nigdy „obok Chrystusa”. Taką możliwość pośrednictwa Maryi przyjmuje H. Asmussen. Jego przemyślenia stały się inspiracją dla Jana Pawła II, który w encyklice Redemptoris Mater promuje model pośrednictwa Maryi „w Chrystusie”.

Ślady, a nawet wyraźne znaki rewaloryzacji maryjności w niemieckim protestantyzmie odkrywa obszerny artykuł Herberta Kinga (ss. 227-259). Zwłaszcza nowopowstające, ewangelickie wspólnoty inspirują się duchowością maryjną. Przyjmują, że wiara rodzi się z doświadczenia spotkania. Maryja budzi miłość i serdeczność, uczucia. Serce ma powody, których nie zna rozum. To nie Maryja mówi o Bogu, ale Jej doświadczenie i osobiste spotkanie z Nią.

Potwierdza to artykuł $\mathrm{w}$ formie świadectwa Josefa Treuleina, proboszcza sanktuarium maryjnego Käppele w Würzburgu i zarazem inicjatora „frankońskich dróg maryjnych", które na przestrzeni 900 kilometrów łączą ze sobą 50 miejsc w Dolnej Frankonii, słynących łaskami (ss. 260-269). Od 2002 roku organizuje J. Treulein konferencje i pielgrzymki maryjne, w których uczestniczą także ewangelicy. Uczestnicy przeżywają spotkania z Maryją, odczuwają Jej macierzyńską więź i pomoc. Doświadczają, że Maryja jest Matką wszystkich chrześcijan i wnosi w ich życie rewolucję czułości. Przekonuje to - sumuje swe refleksje Treulein - że katolików i protestantów dzielą nie tylko teologiczne tre- 
ści, ale i odmienna mentalność, może nawet strach i przyzwyczajenia. Można je zmieniać tylko wtedy, kiedy odnajdziemy „mowę serca” (ss. 268-269).

Pełna jedność między chrześcijanami - przekonuje z kolei Christa Bisang - jest możliwa jedynie wówczas, gdy wszyscy ochrzczeni będą zjednoczeni w jednym, świętym, katolickim i apostolskim Kościele, w duchowej jedności z następcą świętego Piotra. Na dowód przywołuje konwersję amerykańskiego teologa Scotta Hahna, w której istotne znaczenie odegrała Maryja (ss. 270289). Odkrył on w Niej Matkę wszystkich chrześcijan, ma Ona bowiem udział w dziele naszego zbawienia oraz jest pierwszym i najpiękniejszym jego owocem (s. 288).

Motyw Matki jedności przejawia się też w rzymskiej liturgii. Poświęca temu zagadnieniu obszerny artykuł Johannes Nebel (ss. 290-333). W pierwszej jego części dokonuje przeglądu mszału rzymskiego, by wydobyć z niego treści i sformułowania, które wskazują na udział Maryi w dziele chrześcijańskiej jedności (ss. 291-312). Zauważa, że pojawia się Ona tam, gdzie jest mowa o miłości, pokoju i zgodzie. Występuje też jako wzór miłości i służebnica pokoju. O wiele ciekawsza jest druga część artykułu, w której J. Nebel koncentruje się na 38. formularzu mszału maryjnego, zatytułowanym: Maryja, Matka jedności (ss. 323-333). Samo umieszczenie go w oficjalnej księdze liturgicznej zasługuje - jego zdaniem - na uznanie. Składowe elementy (czytania, Ewangelia, antyfony, modlitwy, prefacja), które wnikliwie analizuje, wyrażają w duchu nauczania soborowego prawdę, że Maryja odgrywa doniosłą, wręcz niezbędną rolę w budowaniu chrześcijańskiej więzi.

W następnym artykule Gertrud Pollak pokrótce przedstawia poruszającą historię z kręgu duchowości szensztackiej. Nosi ona tytuł: Cruz de la unidad („Krzyż jedności” - s. 334-343), a zrodziła się z inspiracji latynoskiego kleryka studiującego w Chile, konstruktora krzyża, na którym widnieje Maryja, Matka w ścisłej jedności z Jezusem, swoim Synem. Jawi się Ona jako Jego wierna towarzyszka i współpracownica. Każda miłość skierowana do Niej prowadzi jednocześnie do Jezusa Chrystusa, do zjednoczenia z Nim, a zjednoczenie to ostatecznie wiedzie ku Ojcu w jedności Ducha. Taka interpretacja wizerunku z Chile przyjęła się w rodzinie szensztackiej.

$\mathrm{W}$ ostatnim artykule, odbiegającym tematycznie od pozostałych, usiłuje się odnaleźć i odczytać maryjne przesłanie dzieł niemieckiego poety Johanna Wolfganga von Goethe (ss. 344-388). Wolfgang Koch koncentruje się szczególnie na poszukiwaniu w nich odniesień do obiecanego znacznie później w Fatimie ostatecznego triumfu Maryi, triumfu Jej niepokalanego Serca.

Nasuwa się finalny wniosek, że nie dziwi fakt, iż mariologiczna konferencja w Würzburgu spotkała się z żywym i przychylnym oddźwiękiem w niemieckich mediach. Wszystkie opublikowane z niej materiały zasługują na uznanie. Spra- 
wiają wrażenie rzetelnych opracowań. Bazują na źródłach, są bogato udokumentowane. Cechuje je wnikliwość analiz i umiarkowanie w wyprowadzanych konkluzjach. Pożytecznym dopowiedzeniem do przedłożonych refleksji są liczne i celnie dobrane przypisy. Uznanie budzi ponadto wieloaspektowe ujęcie problemu: nie brakuje refleksji biblijnych i patrystycznych na temat Maryi-Matki jedności. Niektóre artykuły odwołują się nie tylko do teologii, ale i do chrześcijańskiego doświadczenia, które jest ważnym miejscem teologicznym. Oczywiście, najbardziej reprezentowane są refleksje XX wieku, kiedy to tytuł „Matka jedności” stawał się coraz bardziej popularny i powszechny. Cenne są głosy i uwagi strony ewangelickiej. Szkoda natomiast, że zabrakło odniesienia prawosławnego. Zbyt pobieżnie zostało potraktowane nauczanie papieskie, szczególnie Pawła VI i Jana Pawła II, którzy przyczynili się do recepcji tego maryjnego tytułu w życiu posoborowego Kościoła. W ostatnich latach coraz częściej dostrzega się w Maryi „Zwornik” międzyreligijny, szczególnie na linii islam chrześcijaństwo. Interesujące byłyby pogłębione przemyślenia na ten temat.

W sumie jednak wielorakie walory omawianej pracy zbiorowej górują zdecydowanie nad podniesionymi wątpliwościami i niedociągnięciami, które nie tyle są uwagami krytycznymi, ile raczej dyskusyjnymi. Nie umniejszają one wartości merytorycznej publikacji. Stanowi ona cenny przyczynek na polu mariologii i ekumenizmu, gdyż otwiera nowe perspektywy w zgłębianiu tajemnicy Maryi. Pogłębione zajmowanie się nią sprawia, że w nowy sposób postrzega się kwestię jedności chrześcijańskiej. Nie trzeba się w pełni zgadzać z przedkładanymi przez autorów poglądami. Inspirują one jednak do dalszych poszukiwań na linii Maryjajedność Kościoła. Choćby tylko z tego powodu warto się z nimi zapoznać.

Adam Wojtczak ${ }^{38}$
Uniwersytet im. Adama Mickiewicza w Poznaniu, Poznań, Polska
Wydział Teologiczny

${ }^{38}$ O. Adam Wojtczak OMI - ur. 1955, dr hab. prof. UAM, autor pięciu monografii: Uczennica i Matka. Wokót chrystocentryzmu mariologii Jana Pawła II; Matka i Królowa. Ku integralnemu i pogtębionemu tytutów maryjnych; ,Serva Domini”. Z maryjnego nauczania Benedykta XVI; Symboliczne inwokacje Litanii loretańskiej. Historia - teologia - kult; Czułe oblicze Matki. Przewodnie motywy mariologii Papieża Franciszka, autor ponad 80 artykułów z zakresu mariologii i teologii eucharystycznej, opublikowanych w polskich i zagranicznych czasopismach, członek Towarzystwa Teologów Dogmatyków, Polskiego Towarzystwa Mariologicznego i Pontificia Academia Mariana Internationalis, e-mail: adam.wojtczak@oblaci.net. ORCID: 0000-00016431-2116. 


\section{Book review Maria, „Mutter der Einheit” (,Mater unitatis”) ed. M. Hauke,} Regensburg 2020, pp. 392

\section{Summary}

The collective work is the fruit of a symposium held in 2018 in Würzburg on Mary, Mother of Unity. It consists of eighteen articles. The first shows Mary's concern for unity as a manifestation of her spiritual motherhood. The next two present the Mother of Unity in the perspective of the Gospels of John and Luke. In the following texts, the teachings of St. Augustine, St. J.H. Newman, Leo XIII, Ch. Lubich, and the Second Vatican Council are brought to bear on the same theme. There is no lack of Protestant positions (K. Barth and H. Asmussen) and the motif of the Mother of Unity in the Roman liturgy and Schoenstatt spirituality. The final article attempts to read the Marian message of the German poet J.W. Goethe. All articles deal mainly with unity in an ecclesial and ecumenical perspective.

\section{Keywords}

Mary, Mother of unity, Church, ecumenism, Mariology

\section{Słowa kluczowe}

Maryja, Matka jedności, Kościół, ekumenizm, mariologia 